\title{
Keuzemogelijkheden binnen en tussen pensioenregelingen: niet voor elk wat wils ${ }^{*}$
}

\author{
Lei Delsen $^{* *}$
}

\section{$1 \quad$ Inleiding}

Aanvullend pensioen is een belangrijke secundaire arbeidsvoorwaarde die verplicht voor bijna alle Nederlandse werknemers geldt. Keuzemogelijkheden zijn hier beperkt of zelfs afwezig. Deelnemers hebben bovendien nagenoeg geen invloed op het beleggingsbeleid van pensioenfondsen. Paternalisme heerst. Sociale partners en pensioenfonds bepalen wat de werknemers nodig hebben en wat goed voor hen is. Zij bepalen het indexatie-, premie- en beleggingsbeleid. Deze 'one size fits all'-aanpak knelt, schrijft de Sociaal-Economische Raad (SER) in zijn ontwerpadvies over de toekomst van het pensioenstelsel (SER, 2015). De SER vraagt zich af of niet meer maatwerk en keuzevrijheid wenselijk zijn, nu de risico's meer bij de deelnemers komen te liggen en de financiële ruimte en de risicodraagkracht van deelnemers variëren. Volgens recent onderzoek in opdracht van het ministerie van Sociale Zaken en Werkgelegenheid, in het kader van de 'Nationale Pensioendialoog', willen Nederlanders meer keuzemogelijkheden ten aanzien van het eigen pensioen. Er is behoefte aan individuele keuzevrijheid, zowel bij de pensioenopbouw als bij de pensioenuitkering (Koenen, 2014). Door individuele keuzevrijheid kan de pensioenfondsdeelnemer rekening houden met zijn individuele financiële voorkeuren (risico- en onzekerheidsaversie) en niet-financiële voorkeuren (duurzaam beleggen). Hiermee kan welvaartswinst worden geboekt. Keuzemogelijkheden bevorderen bovendien het pensioenbewustzijn. Een grotere keuzevrijheid kan ook het vertrouwen in het pensioenstelsel vergroten en daarmee de houdbaarheid (Commissie Goudswaard, 2010). Met name verzekeraars stellen dat werkgevers de vrijheid moeten krijgen om zelf te bepalen bij welke pensioenuitvoerder zij de pensioenregeling willen onderbrengen (Verbond van Verzekeraars, 2014). Kan de gewenste keuzevrijheid binnen de aanvullende pensioenen gecombineerd worden met collectief georganiseerde solidariteit - de centrale waarden van het Nederlandse pensioenstelsel? Die vraag is temeer relevant nu één op de vijf werkenden (flexwerkers en zelfstandigen) geen of onvoldoende aanvullend pensioen opbouwt.

In dit artikel worden de voors en tegens besproken - de grenzen verkend - van keuzemogelijkheden van werkenden en werkgevers binnen en tussen pensioenre-

* $\quad$ Deze paper kwam mede tot stand met subsidie van de Stichting Instituut Gak. Met dank aan de anonieme referent, Eelke de Jong en Esther-Mirjam Sent voor hun commentaar op een eerdere versie.

** Dr. Lei Delsen is universitair hoofddocent sociaaleconomisch beleid aan de Radboud Universiteit, Institute for Management Research, en research fellow van het Network for Studies on Pensions, Aging and Retirement (Netspar). L.Delsen@fm.ru.nl 
gelingen. Hoe ziet het optimale pensioencontract er in de praktijk uit? Psycholoog Kurt Lewin $(1945,129)$ parafraserend: er is niets zo praktisch als een goede theorie; zij maakt zichtbaar wat voordien niemand zag. De neoklassieke economische theorie, de neo-institutionele theorie en de gedragseconomische theorie worden toegepast op de aanvullende pensioenen. In de neoklassieke rationele keuzetheorie zijn individuele keuzes gebaseerd op een rationele, logische afweging van alle opties, waarbij het maximaal haalbare voor het individu centraal staat. De neoinstitutionele theorie brengt de neoklassieke micro-economische theorie dichter bij de realiteit door de introductie van transactie- en informatiekosten. De gedragseconomie start vanuit de neoklassieke economische theorie, maar vult die aan met inzichten uit andere sociale wetenschappen, vooral de psychologie, om economische keuzes van individuen te verklaren. Daarnaast worden lessen getrokken uit de ervaring in Nederland met de bestaande keuzemogelijkheden binnen pensioenregelingen en met keuzes binnen de cao à la carte, de spaarloonregeling, de levensloopregeling en de Zorgverzekeringswet.

In paragraaf 2 worden de theoretische en beleidsmatige argumenten voor maatwerk en meer keuzevrijheid binnen de aanvullende pensioenen kritisch besproken. Mede door hoge transactiekosten leidt noch maatwerk, noch individuele keuzevrijheid in de praktijk tot het neoklassieke optimale pensioencontract. In de praktijk is een optimaal pensioen niet gelijk aan maximaal pensioen. Paragraaf 3 gaat in op de ervaring met en de meningen van deelnemers over de bestaande keuzemogelijkheden binnen de tweede pensioenzuil. De meerderheid wil meer keuzemogelijkheden en zeggenschap, ondanks grote onwetendheid en gebrek aan kennis over mogelijke gevolgen. Aangetoond wordt dat de voorkeuren van mensen ten aanzien van keuzevrijheid op pensioengebied en de gemaakte keuzes sterk afhangen van de manier van vraagstelling en hoe de keuzemogelijkheden ontworpen zijn. De vraag welke beleidslessen uit de gedragseconomie kunnen worden getrokken voor het ontwerpen van keuzemogelijkheden, wordt in paragraaf 4 beantwoord. De gevolgen van de opheffing van de zogenoemde grote en de kleine verplichtstelling staan centraal in paragraaf 5 . Dit raakt de kern van het aanvullend pensioen, de risicodeling tussen en binnen generaties. Er wordt een relatie gelegd tussen de omvang van de witte vlekken op pensioengebied en keuzevrijheid voor werknemers en werkgevers en de toenemende segmentering binnen bedrijven en op de arbeidsmarkt. Conclusies sluiten het artikel af.

\section{Optimaal pensioencontract en individuele keuzevrijheid}

\subsection{Arbeidsvoorwaarde of financieel product?}

Collectiviteit, solidariteit en vertrouwen zijn de centrale waarden van het Nederlandse pensioenstelsel. Uit peilingen van De Nederlandsche Bank (DNB) blijkt dat het publieke vertrouwen in het eigen pensioenfonds tussen 2007 en 2012 is gedaald met 30 procentpunten naar 55 procent, een score die beduidend lager ligt dan de scores voor banken en verzekeraars (DNB, 2012). In 2013 is het vertrouwen in pensioenfondsen met 2 procentpunten gestegen tot 57 procent, maar nog 
steeds 28 procentpunten lager dan voor de crisis. Het Centraal Bureau voor de Statistiek (CBS) geeft de volgende cijfers voor 2012. Van de werknemers die via hun werkgever pensioen opbouwen, heeft 55 procent niet zo veel of zelfs helemaal geen vertrouwen in hun pensioenfonds of pensioenverzekeraar. Mannen hebben meer vertrouwen dan vrouwen, ouderen meer dan jongeren, en hoogopgeleiden en hogere inkomens meer dan laagopgeleiden en lagere inkomens. Weinig vertrouwen in pensioenfondsen gaat samen met zorgen over inkomen op latere leeftijd (CBS, 2012a). In 2013 maakte 32 procent van de Nederlanders zich zorgen om het eigen pensioen, in 201438 procent (Koenen, 2014).

Het aanvullend pensioen kan worden opgevat als uitgesteld loon en is daarmee een arbeidsvoorwaarde. ${ }^{1}$ Pensioengelden zijn eigendom van de werknemers. Wie betaalt, bepaalt. In tegenstelling tot reguliere aandeelhouders hebben de eigenaren van pensioenfondsen weinig of geen invloed op het beleid en vooral niet op de beleggingsbeslissing. De economische wetenschap beïnvloedt de realiteit. Geloof in de heilzame werking van de markt heeft invloed op ons denken en handelen. In de Nederlandse samenleving is de rol van markten en contracten groot. Mensen worden geacht het eigenbelang na te streven. Het gedrag van de Nederlander wordt hierdoor calculerender en (arbeids)relaties worden zakelijker. Pensioenfondsdeelnemers - werknemers, slapers en gepensioneerden - worden als consumenten beschouwd. Pensioenen zijn steeds minder een arbeidsvoorwaarde, maar worden in toenemende mate een financieel product waaraan de consumenten waarde hechten en een bepaald gevoel bij hebben (Kortleve \& Slager, 2010). Pensioenfondsen zijn een aanbiedende partij op een deel van de markt voor oudedagsvoorzieningen (De Laat, Van de Ven \& Canoy, 2000).

Economie is de wetenschap van de keuze. Schaarse middelen dwingen keuzes af. De gangbare neoklassieke micro-economische theorie start vanuit vooronderstellingen over de voorkeuren, de preferenties van mensen, en vraagt vervolgens wat er zal gebeuren. Het rationele keuzemodel staat centraal in economische analyses. In de neoklassieke economische theorie hebben deelnemers van pensioenfondsen slechts financiële belangen. De doelstellingsfunctie van het individu bepaalt in sterke mate het optimale beleid van pensioenfondsen ten aanzien van premie, indexering en beleggingen (Boender e.a., 2006). De neoklassieke beleggingstheorie is een belangrijk uitgangspunt van het beleggingsbeleid van Nederlandse pensioenfondsen. Waar bedrijven streven naar winstmaximalisatie, streven pensioenfondsen naar een zo hoog mogelijk beleggingsresultaat. Bedrijfsethiek is daarmee strijdig met efficiëntie, en aan maatschappelijke betrokkenheid zijn hoge kosten verbonden (Delsen, 2012). De neoklassieke analyse richt zich op de productiekosten. Verondersteld wordt dat mensen rationeel handelen en dus vrijwillig sparen voor hun oude dag. Het rationele individu wordt daarbij geacht het nut van de verwachte consumptie in elk toekomstig jaar te maximeren. Meer is beter. Het rationele keuzemodel impliceert ook dat veel keuzemogelijkheden gewenst zijn. Het maakt vergelijking van alternatieven mogelijk en vergroot de kans op het vinden van een volledig passend alternatief (Van Raaij \& De Groot, 2007). In de neoklassieke economische theorie zijn de transactiekosten afwezig: verwerven en 
hanteren van informatie is kosteloos en informatie is onmiddellijk beschikbaar. De preferenties verschillen met betrekking tot de consumptie gedurende het leven. Er is heterogeniteit in de mate van risicoaversie en in de voorkeuren voor onzekerheid van de pensioenfondsdeelnemers. Samen met de veronderstelde nutsmaximalisatie vormen zij het argument om de keuzes in de handen van de individuele pensioenfondsdeelnemer te geven. Overheidsbeleid van marktwerking en meer keuzevrijheid veronderstelt dat pensioenfondsdeelnemers bereid en in staat zijn een zorgvuldige afweging te maken en het beste alternatief te kiezen (Van Raaij \& De Groot, 2007).

De gedragseconomie en de neo-institutionele economie plaatsen vraagtekens bij dit op neoklassieke leest geschoeide beleid. ${ }^{2}$ De gedragseconomie relativeert het op rationele wijze maximeren van de eigen opbrengsten, de nutsmaximalisatie, die wordt verondersteld in de rationele keuzetheorie. Naast maximizers, mensen die handelen conform het rationele keuzemodel, zijn mensen vooral satisficers, die tevreden zijn met een keuze die goed genoeg is (Simon, 1957). Bovendien doen zich gedragseffecten voor, waardoor gemaakte pensioenkeuzes suboptimaal zijn. Meer keuzemogelijkheden maakt niet altijd gelukkiger (Iyengar \& Lepper, 2000; Schwartz, 2004). De neo-institutionele theorie veronderstelt dat mensen beperkt rationeel handelen en opportunistisch zijn (Williamson, 1985). Economische actoren beschikken in de praktijk niet over alle voor een beslissing relevante informatie. Bovendien is die informatie ongelijk verdeeld. Dat geldt eveneens voor de capaciteit om met deze informatie om te gaan. Pensioencontracten komen hierdoor niet kosteloos tot stand. Bij de introductie van keuzes dient rekening te worden gehouden met zowel de productie- als de transactiekosten. Vertrouwen tussen partijen, maar ook informatie- en communicatietechnologie kunnen de transactiekosten reduceren en zijn medebepalend voor zowel de optimale schaalgrootte van pensioenfondsen als het optimale assortiment aan pensioenproducten.

\subsection{Toename heterogeniteit pensioenfondsdeelnemers}

Binnen pensioenfondsen liggen de risico's in toenemende mate bij de deelnemers. De pensioenfondsen zijn steeds minder goed in staat de risico's op te vangen. Bedrijven willen steeds minder pensioenrisico's dragen. De ambitieverlaging in de tweede pensioenpijler betekent dat pensioenfondsdeelnemers een grotere individuele verantwoordelijkheid dragen. Een grotere keuzevrijheid kan het vertrouwen in het pensioenstelsel vergroten en daarmee bijdragen aan de houdbaarheid (Commissie Goudswaard, 2010). Overheidsbeleid van marktwerking en meer keuzevrijheid veronderstelt sterke betrokkenheid (Van Raaij \& De Groot, 2007). In de lopende pensioendialoog wordt deze relatie omgekeerd: keuzevrijheid leidt tot meer betrokkenheid van de deelnemers (SER, 2015). 'Pensioenproducten' worden dan aantrekkelijker. Betrokkenheid legt echter ook de verschillen in belangen tussen de pensioenfondsdeelnemers bloot. Transparantie en meer keuzevrijheid vergroten het pensioenbewustzijn (Kortleve \& Slager, 2010). Pensioenbewustwording leidt tot meer individualisering. Ook toenemende arbeidsmobiliteit en heterogeniteit in de voorkeuren leiden tot individualisering en gaan ten koste van 
solidariteit. Toenemende individualisering, een hoger opleidingsniveau en heterogeniteit kunnen vervolgens weer leiden tot een grotere behoefte aan keuzevrijheid en maatwerk binnen het pensioenstelsel (Van Ewijk e.a., 2014; Dellaert \& Ponds, 2014).

De neoklassieke economische theorie veronderstelt dat keuze en concurrentie voordelig zijn indien de consument goed geïnformeerd is. De welvaart wordt dan gemaximeerd. Meer marktwerking en keuzevrijheid moeten gepaard gaan met betere transparantie (De Laat e.a., 2000). Conform de neoklassieke theorie wordt in het Nederlandse beleid meer pensioeninformatie niet alleen gebruikt om te komen tot betere keuzes, maar ook om het vertrouwen in de tweede pensioenzuil te vergroten. Ook vergroting van de pensioenkennis krijgt veel aandacht in het Nederlandse pensioenbeleid. Dit beleid is niet effectief. De kennis van Nederlanders over hun eigen pensioenvoorziening was en blijft beperkt. Nederlanders zijn niet erg bewust bezig met hun pensioen. Het pensioenbewustzijn van zowel werknemers als zelfstandigen is laag (Prast \& Van Soest, 2014). Volgens Van der Lecq en Steenbeek $(2006,274)$ kan grotere transparantie negatieve gevolgen hebben voor de houdbaarheid van het huidige stelsel, omdat veel solidariteit bestaat bij de gratie van onwetendheid. Meer transparantie kan ook het vertrouwen in pensioenfondsen verminderen (Van Raaij, 2009). Grotere keuzevrijheid maakt bovendien het toch al complexe pensioenproduct nog ingewikkelder. Individuele verantwoordelijkheid brengt gezien het geringe pensioenbewustzijn ook risico's op 'ongelukken' met zich. Het is daarom van belang een juiste balans te vinden tussen verplichting en keuze (Commissie Goudswaard, 2010; Bonenkamp e.a., 2011).

Pensioenfondsen kunnen hun product eveneens aantrekkelijker maken door deelnemers met verschillende kenmerken ook verschillende pensioenoplossingen te bieden. Maatwerk is meer dan keuzevrijheid voor de individuele deelnemer (Nijman \& Oerlemans, 2008). Volgens toezichthouders DNB en Autoriteit Financiële Markten (AFM) dienen pensioenfondsen te beleggen conform de risicobereidheid van de deelnemers. Echter, ook niet-financiële belangen spelen bij de deelnemers van pensioenfondsen. De commissie-Frijns (2010) concludeert dat maatschappelijk verantwoord handelen geen geïntegreerd onderdeel is van het risicobeheer en het beleggingsbeleid van pensioenfondsen. Zij doet de aanbeveling aan de besturen van pensioenfondsen om de preferenties van de deelnemers en de premiebetalende werkgevers met betrekking tot duurzaamheid als uitgangspunt voor het risico- en beleggingsbeleid te nemen. Nederlanders vinden verantwoord beleggen door pensioenfondsen belangrijk. Uit diverse enquêtes komt naar voren dat de overgrote meerderheid (driekwart) bereid is voor de realisatie van deze niet-financiële doelen een hogere premie te betalen of pensioeninkomen in te leveren (Erbé, 2008; Motivaction, 2012; Borgers \& Pownall, 2014). Overeenstemming van belangrijke normen en waarden tussen pensioenfonds en deelnemers door bijvoorbeeld duurzaamheid centraal te stellen, draagt bij tot herstel van het vertrouwen (Van Raaij, 2009). 
Vooral wanneer individuele preferenties, behoeften en omstandigheden sterk verschillen, leiden uniforme pensioenregelingen en verplichtstelling tot welvaartsverlies. Het 'one size fits all'-beleid van pensioenfondsen, waarbij alle deelnemers dezelfde pensioenpremie betalen en waarbij hetzelfde opbouwpercentage geldt (doorsneepremie en doorsneeopbouw), stemt dan niet overeen met de heterogeniteit van de deelnemers en is suboptimaal. Dit is temeer van belang daar deelnemers niet kunnen overstappen naar een andere pensioenaanbieder. De heterogeniteit in omstandigheden (zoals arbeidscontract, menselijk kapitaal en gezondheid) maakt individueel maatwerk in een pensioenoplossing belangrijk en betekent dat het optimale pensioencontract van individu tot individu verschilt (Nijman \& Oerlemans, 2008). In de pensioenliteratuur wordt gesteld dat pensioenfondsdeelnemers heterogener en veeleisender zijn geworden. Daaraan gekoppeld is de roep om consumentensoevereiniteit en maatwerk. Individuen kennen hun preferenties en omstandigheden het beste (zie bijvoorbeeld De Laat e.a., 2000; Nijman \& Oerlemans, 2008; Bovenberg, Van Ewijk \& Westerhout, 2012; Dellaert \& Ponds, 2014). Er kan welvaartswinst worden geboekt door de introductie van keuzes en maatwerk, door de pensioencontracten af te stemmen op de preferenties en karakteristieken van de deelnemers. De inhoud van de aanvullende pensioenregelingen in Nederland is gebaseerd op homogeniteit van de deelnemers binnen een bedrijfstak, onderneming of beroepsgroep. Ook de commissieGoudswaard (2010) constateert dat de heterogeniteit van de deelnemers en de heterogeniteit van preferenties binnen eenzelfde collectieve regeling lijken te zijn toegenomen. $\mathrm{Zij}$ beveelt daarom aan de mogelijkheden van meer keuzes te onderzoeken om aan te sluiten bij deze heterogene preferenties.

\subsection{Optimaal pensioen is niet maximaal pensioen}

Het neoklassieke optimale pensioencontract komt in de praktijk niet voor. Binnen een collectieve regeling kan het keuzemenu onmogelijk zo omvangrijk zijn dat alle individuele pensioenwensen daarin gerealiseerd worden (Nijman \& Oerlemans, 2008). Pensioenfondsen beschikken niet over alle informatie van de individuele deelnemers met betrekking tot hun omstandigheden, kenmerken en voorkeuren. Prohibitieve transactiekosten en privacyoverwegingen spelen hierbij een rol. Informatietechnologie maakt het echter steeds beter mogelijk in te spelen op individuele voorkeuren en omstandigheden. Bijvoorbeeld, bestanden met beschikbare informatie van de werkgever (leeftijd, partner, kinderen) en de Belastingdienst (vermogen, schulden) kunnen gekoppeld worden (Nijman \& Oerlemans, 2008; Bodie \& Prast, 2012; Bovenberg e.a., 2012; Dellaert \& Ponds, 2014). Daarnaast dient er ruimte te zijn voor individuele keuzemogelijkheden. Echter, ook individuele keuzevrijheid leidt niet tot het theoretisch optimale pensioencontract. Volledige keuzevrijheid en grote flexibiliteit gaan gepaard met te weinig pensioensparen en pensioeninkomen (onderverzekering) en welvaartsverlies (Van Els, Van Rooij \& Schuit, 2006, 199-201; Barr \& Diamond, 2008, 174-175). De gemaakte keuzes kunnen niet altijd onderbouwd worden als het resultaat van maximeren van de preferenties door de pensioenfondsdeelnemer, zoals de neoklassieke economische theorie veronderstelt. Het neoklassieke model verschilt fundamenteel van de praktijk. Uit veel nationaal en internationaal 
onderzoek blijkt dat mensen niet goed kunnen omgaan met de complexe keuzes ten aanzien van de oude dag (zie bijvoorbeeld Mitchell \& Utkus, 2004; Bovenberg e.a., 2012). Veel mensen proberen hun persoonlijk welzijn te maximaliseren, maar zij blijken veel coöperatiever en altruïstischer dan de economische theorie voorspelt dat ze zullen zijn (Mitchell \& Utkus, 2004). Iedere mens is tegelijkertijd een individualist en een sociaal wezen. De neoklassieke rationele actor is een slechte basis voor het beleid ten aanzien van keuzemogelijkheden in pensioenregelingen. Simon (1957) onderscheidt twee soorten mensen. Maximizers vormen een kleine minderheid die altijd probeert de beste optie te kiezen uit de beschikbare opties. De grote meerderheid bestaat uit satisficers, mensen die eenvoudig naar een keuze zoeken die goed genoeg is. Meer is niet beter; meer is minder. Toename van het aantal (complexe) keuzemogelijkheden leidt tot keuzestress. Maximizers zijn minder tevreden en minder gelukkig met hun keuzes dan satisficers. De gemaakte kosten, hoge verwachtingen en hoge eisen wegen niet op tegen het resultaat. Verkeerde keuzes zijn voor een satisficer minder erg. Zij kampen minder vaak met depressies (Iyengar \& Lepper, 2000; Schwartz, 2004). Optimaal is niet gelijk aan maximaal. Een zeker pensioen, een bepaald ambitieniveau, is een realistischere doelstelling dan meer is beter (Bodie, Snippe \& Prast, 2008). Met betrekking tot pensioensparen is er veel uniformiteit in preferenties en gewenst resultaat: een veilig oudedagsinkomen is kwalitatief gelijk voor iedereen (Barr \& Diamond, 2008). Introductie van keuzemogelijkheden is bovendien geen eenmalige activiteit. Maatwerk vereist voortdurende aanpassing van het pensioenproduct aan veranderingen in persoonlijke preferenties en omstandigheden. Dit voortdurend handelen van zowel pensioenfonds als deelnemer gaat gepaard met transactiekosten, die in de neoklassieke benadering buiten beschouwing blijven. Individuele pensioenregelingen hebben aanzienlijk hogere uitvoeringskosten en zijn minder efficiënt dan collectieve pensioenenvoorzieningen en dat gaat ten koste van de pensioenopbouw (Bikker \& De Dreu, 2006).

\section{Meer keuzevrijheid gewenst ondanks kennisgebrek}

\subsection{Bestaande keuzemogelijkheden}

Discussie over meer keuzemogelijkheden is niet nieuw. In de jaren negentig van de vorige eeuw is al een aantal actuarieel neutrale keuze-elementen binnen de tweede pensioenzuil geïntroduceerd (Delsen, 2001). Door de herziening van de Wet fiscale behandeling van pensioenen van 1999 zijn vervroegen of uitstellen van pensioenleeftijd, deeltijdpensioen, eerst een hogere, dan een lagere pensioenuitkering (hoog-laagconstructies) en bijsparen mogelijk. Daarnaast bestaat vanaf 1994 de keuze voor waardeoverdracht en vanaf 2001 de keuze voor gehele of gedeeltelijke uitruil van nabestaandenpensioen voor een hoger of eerder ingaand ouderdomspensioen. Bij beschikbare premieregelingen bestaat soms enige mate van beleggingsvrijheid. Van recentere datum zijn de inzet van het tegoed van de levensloopregeling voor vroegpensioen/aanvullend pensioen en pensioen voor zelfstandigen. 
Onderzoek naar feitelijk gemaakte keuzes binnen de bestaande keuzemogelijkheden door pensioenfondsdeelnemers is nagenoeg afwezig. Binnen het Algemeen Burgerlijk Pensioenfonds (ABP) maakt 25 tot 30 procent daadwerkelijk gebruik van de flexibele pensioenleeftijd en van deeltijd- en hoog-laagpensioen (Dellaert \& Ponds, 2014). Studies zijn vooral theoretisch en beschrijvend van aard en beperken zich in hoofdzaak tot de wensen van deelnemers (zie bijvoorbeeld Bodie e.a., 2008; Nijman \& Oerlemans, 2008; Kortleve \& Slager, 2010; Kooreman \& Prast, 2010; Dietvorst \& Visser, 2012). Enquêteresultaten laten zien dat vooral deeltijdpensioen de toekomst heeft. Bijna de helft van de respondenten geeft aan hiervan gebruik te zullen gaan maken, gevolgd door vervroegd uittreden (Dietvorst \& Visser, 2012). Dit zijn relatief eenvoudige keuzes met overzichtelijke consequenties en een korte tijdsperiode tussen beslissing en effectuering. Ook binnen de complexe levensloopregeling waren dit de belangrijkste spaarmotieven (Delsen \& Smits, 2014). Partnerpensioen, langer doorwerken en variatie in pensioenuitkeringshoogte (AOW-compensatie) hebben minder belangstelling. Er is grote onwetendheid over het bestaan van deze persoonlijke keuzemogelijkheden en de financiële gevolgen ervan. Mogelijke verklaringen voor de onwetendheid zijn volgens Dietvorst en Visser (2012) de algemene desinteresse in pensioenen en de complexiteit van de opties. Van de FNV-leden die nog niet met pensioen zijn, geeft 43 procent aan dat er (veel) te weinig keuzevrijheid is binnen pensioenen. Zij willen vooral de hoogte en de leeftijd van pensioen zelf kunnen kiezen. Ruim een derde (36 procent) is niet bereid voor meer keuzevrijheid pensioen in te leveren; 41 procent wel. Een kwart weet niet wat er nu al te kiezen valt. Voor leden onder de 45 jaar is dat 29 procent (FNV, 2014). Elke keuze impliceert expliciet of impliciet een default, de optie als er geen actie wordt ondernomen (Nijboer \& Boon, 2012). Benutten van de bestaande keuzemogelijkheden om te komen tot maatwerk binnen de collectieve pensioenproducten vereist optimale communicatie met de deelnemer en het formuleren van adequate defaults, ${ }^{3}$ gedifferentieerd naar homogene groepen deelnemers, zoals leeftijd, mogelijkheid tot langer doorwerken en bestaande pensioenopbouw (Nijman \& Oerlemans, 2008; Bodie \& Prast, 2012). Echter, communicatie over deze mogelijkheden zal slechts een beperkt effect sorteren, gezien de desinteresse bij de ontvanger en de complexiteit van de keuzeopties. Door de complexiteit en bij een groot aantal beschikbare alternatieven kan informatieoverdaad ontstaan (Van Raaij \& De Groot, 2007), waardoor de kwaliteit van beslissingen afneemt.

\subsection{Enquêtevragen sturen pensioenpreferenties}

Enquêteresultaten laten zien dat Nederlanders zowel sterk risicoavers als sterk onzekerheidsavers zijn. Nederlanders zijn erg risicomijdend als het om beleggingskeuzes gaat; een grote meerderheid (driekwart) is voorstander van voorzichtig beleggen, ook als dat een lager dan normaal pensioen oplevert. De helft van de Nederlanders kan geen inschatting maken van de langetermijneffecten van sparen en beleggen. Ook kiest het merendeel (driekwart) van de Nederlanders voor pensioenzekerheid: meer premie betalen voor een gegarandeerd pensioen. $\mathrm{Zij}$ kiezen veel minder voor een lagere premie met een pensioen zonder garanties (Van Els e.a., 2006; Erbé, 2008; Motivaction, 2009, 2012; Kloosterman \& 
Schmeets, 2014). Meer invloed van de deelnemers op het risicobeheer en het beleggingsbeleid van pensioenfondsen betekent dus een veiliger beleggingsbeleid met hogere premies en/of lagere pensioenuitkeringen.

Enquêteresultaten over preferenties worden in belangrijke mate bepaald door de manier waarop de vragen zijn gesteld en de keuzemogelijkheden zijn ontworpen. Uit recent enquêteonderzoek blijkt dat Nederlanders (van 40 jaar en ouder) noch risicoavers, noch onzekerheidsavers zijn op pensioengebied. De respondenten is gevraagd te kiezen tussen vignetten (fictieve casusbeschrijvingen, die zich in de werkelijkheid kunnen voordoen) met hoog, gematigd en laag beleggingsrisico, en vignetten met hoge, gematigde en lage premie en (on)zekerheid van pensioeninkomen na pensionering. De drie risicoprofielen en de drie onzekerheidsprofielen worden elk door ongeveer een derde van de respondenten gekozen. Dat mensen een voorkeur hebben voor de 'middenweg', wordt bevestigd. De gematigde middelste optie wordt relatief het vaakst gekozen (Delsen \& Kantarci, 2014). Dit maakt niet alleen sturing, maar ook manipulatie bij keuzeproblemen mogelijk (Bodie, e.a., 2008). Een verklaring voor dit afwijkende resultaat is dat in de vignetten de prijs van een hoger of lager risico en een hogere of lagere zekerheid is gekwantificeerd. De vignetten dwingen bovendien tot keuzes en tot nadenken over de verschillende pensioenopties.

De meerderheid van de Nederlanders wenst meer keuzemogelijkheden ten aanzien van het eigen pensioen (Koenen, 2014). Dit geldt voor het zelf kunnen kiezen wanneer de uitkering begint (73 procent), met welk risico wordt belegd (60 procent), hoeveel premie per maand te betalen (58 procent), hoe de uitkering per jaar wordt verdeeld (58 procent) en hoeveel jaar premie wordt betaald (56 procent). De belangrijkste reden om meer keuzemogelijkheid te willen hebben, is dat het pensioen dan beter aangepast kan worden aan de persoonlijke situatie (75 procent). Als nadelen van meer keuzemogelijkheden wordt vooral genoemd dat mensen te weinig kennis hebben van pensioenen om hierover keuzes te kunnen maken (55 procent), het risico dat de verkeerde keuze wordt gemaakt (49 procent) en de extra rompslomp (37 procent). Onderzoek van Motivaction (2012) geeft aan dat 62 procent van de Nederlanders meer zeggenschap wil over de manier waarop de pensioengelden worden belegd. Volgens DNB (2010) is de helft (53 procent) van de werknemers voorstander van meer zeggenschap over de pensioenopbouw, al geldt dit minder voor de hoger opgeleiden; 36 procent wil zich in het geheel niet bezighouden met beleggen; 21 procent wil enige keuzemogelijkheid en 15 procent wil vergaande zeggenschap over beleggingen. Uit onderzoek van Erbé (2008) onder actieve deelnemers van Pensioenfonds Zorg en Welzijn (PFZW) en van Pensioenfonds Metalektro (PME) blijkt dat bijna driekwart (71 procent) van de deelnemers meer invloed wil op de invulling van het beleggingsbeleid, ondanks het gebrek aan informatie en kennis.

Voorkeuren en antwoorden op waarderingsvragen zijn niet stabiel in de tijd als gevolg van het leerproces dat heeft plaatsgevonden, de veranderde situatie en de invloed van additionele informatie. Of keuzevrijheid belangrijk of onbelangrijk wordt gevonden, is sterk afhankelijk van de context en de manier waarop de 
enquêtevragen worden gesteld. Bijvoorbeeld, Van Dalen en Henkens laten twee groepen respondenten onafhankelijk van elkaar de wenselijkheid van keuzevrijheid dan wel het ontbreken van keuzevrijheid beoordelen. Het merendeel (60-80 procent) vindt het (zeer) belangrijk dat een aantal genoemde onderdelen (waaronder beleggingsrisico en hoogte inleg) van het pensioencontract automatisch geregeld wordt door het eigen pensioenfonds. Voor diezelfde zaken van het pensioencontract wordt vrijheid (27-82 procent) (zeer) belangrijk geacht. Mensen waarderen het dat zij in principe de eigen pensioenbijdrage mogen bepalen, of de mate van risico in het beleggingsbeleid, maar dat betekent nog niet dat zij deze vrijheid ook daadwerkelijk willen uitoefenen (Van Dalen \& Henkens, 2014).

\section{Gedragseconomie en keuzevrijheid}

\subsection{Suboptimale keuzes door gedragseffecten}

In de psychologie zijn de voordelen van keuze verbonden met autonomie en controle (Iyengar \& Lepper, 2000). Zolang geen prijs hoeft te worden betaald, mag worden verwacht dat mensen positief zullen reageren op meer keuzemogelijkheden die worden gezien als meer autonomie. Dan geldt: keuze is goed en meer keuze is beter. Wanneer mensen in de praktijk geconfronteerd worden met een keuzesituatie, gaan andere mechanismen spelen. Begrensde rationaliteit speelt dan een rol (Simon, 1957). Individuen zijn slechts rationeel tot aan de grens van hun vermogen om informatie te ontvangen en te verwerken. Mensen kunnen vaak niet de volledige gevolgen voorzien van een keuze die zij maken. Ook wanneer er te veel keuzemogelijkheden zijn, zullen mensen ervoor kiezen niet te kiezen en aan de standaardoptie vasthouden, niet alleen vanwege bijziendheid of onvolledige informatie, maar ook doordat bij meer keuzemogelijkheden instant bevrediging en een goed gevoel prevaleren, omdat kortetermijndoelstellingen direct verbonden zijn met emoties en met verbetering van de eigen positie. Bovendien is er het risico de verkeerde keuze te maken (Schwartz, 2004; Lindenberg, 2001a, 2001b). Uit diverse enquêtes rond de eeuwwisseling blijkt dat ongeveer driekwart van de Nederlandse werknemers keuzemogelijkheden binnen de cao wenst. Uitgaande van de door de neoklassieke theorie veronderstelde heterogene voorkeuren van werknemers leiden keuzemogelijkheden tot hoge deelname en tot differentiatie. Beperkte differentiatie in de feitelijke keuzes en een lage deelname duiden op een kloof tussen voorkeuren en aangeboden keuzemogelijkheden, of betekenen dat de aangeboden keuzes slechts aansluiten bij een deel van het personeel. Uit diverse onderzoeken blijkt dat het uitzonderlijk is wanneer meer dan een minderheid (30-35 procent) feitelijk deelneemt in de cao à la carte. De relatief lage deelname, beduidend lager dan vooraf verwacht, en de feitelijk eenzijdige keuzes voor 'geld voor tijd' die gemaakt worden wijzen op een geringe effectiviteit en efficiëntie van de opties in de keuze-cao's. Het gevolg is dat uniformering van de arbeidsvoorwaarden niet via regelgeving maar door de markt plaatsvindt. Deze cafetariasystemen vergroten bovendien de ongelijkheid tussen de 'haves' en de 'havenots' op de arbeidsmarkt (Delsen, Benders \& Smits, 2006; Benders \& Delsen, 2007). Voor de beoordeling van de effectiviteit en de efficiën- 
tie van meer keuzemogelijkheden binnen de aanvullende pensioenen is de ervaring met individuele spaarregelingen mogelijk nog relevanter. De deelname aan de complexe levensloopregeling, met een lange en daarmee onzekere spaarperiode, was absoluut laag (3-4 procent van alle werknemers) en veel lager dan verwacht. De deelname aan de eenvoudige en fiscaal gunstigere spaarloonregeling, met een korte spaarperiode, was met 32-40 procent van alle werknemers hoger dan verwacht en fungeerde als default. De deelname aan beide individuele spaarregelingen nam fors toe met het salarisniveau en met het aantal wekelijkse arbeidsuren. Als gevolg van budgettaire beperkingen kunnen niet alle werknemers geld sparen. Meer keuzemogelijkheden en grotere soevereiniteit leiden tot averechtse selectie, inherent aan geïndividualiseerde en actuarieel neutrale spaarsystemen. De transactiekosten voor de werkgever én de werknemer van dit soort individuele keuzeregelingen zijn bovendien aanzienlijk (Delsen \& Smits, 2014). De Zweedse ervaring met keuzemogelijkheden binnen het pensioensysteem laat zien dat individuele autonomie weinig oplevert, al helemaal als het aantal keuzemogelijkheden groot is. Het merendeel van de deelnemers neemt de standaardoptie en kiest niet. De enkele procenten die wel kiezen worden gevormd door de groep die actief gebruik kan en wil maken van de keuzemogelijkheden (Kortleve \& Slager, 2010).

Individuele beslissingen zijn niet altijd in het belang van de persoon: de kosten van ondernemen van actie zijn onmiddellijk en concreet, terwijl de baten in de toekomst liggen en abstract zijn (Mitchell \& Utkus, 2004; Thaler \& Sunstein, 2003; Kooreman \& Prast, 2010; Nijboer \& Boon, 2012). Er zijn allerlei gedragseffecten die ertoe leiden dat individuen suboptimale keuzes maken. Mensen vertonen uitstelgedrag, geven de voorkeur aan de huidige situatie (inertie) en hebben gebrek aan zelfbeheersing en wilskracht. Een van de belangrijkste bevindingen uit de gedragsfinanciële literatuur met betrekking tot pensioenen is dat mensen minder sparen dan rationeel wenselijk is. De neoklassieke theorie veronderstelt een constante discontovoet. In de praktijk zijn preferenties tijdsinconsistent. Uit de psychologie is bekend dat mensen bijziend zijn (hyperbolic discounting). De discontovoet neemt af naarmate de opbrengst verder in de toekomst ligt. Hierdoor zijn gemaakte keuzes tijdsinconsistent. Een genomen beslissing gebaseerd op preferenties van dat moment wordt later betreurd. Mensen zien wel de lasten van de pensioenpremie, maar niet of veel minder de waarde van de pensioenuitkering in de toekomst die daar tegenover staat. Het gevaar bestaat dat individuen ervoor kiezen helemaal niet te sparen, ook als zij hierdoor feitelijk slechter af zijn. Bovendien, niet iedereen is geïnteresseerd in het maken van actieve en goed geïnformeerde financiële keuzes. Integendeel, passief kiezen is algemeen. De defaultoptie is cruciaal bij elke spaar- of investeringsbeslissing. Sociale interactie kan dit versterken wanneer de beslissing van andere deelnemers wordt gevolgd. Dit kuddegedrag kan rationeel zijn bij een complex product, zoals het aanvullend pensioen (zie bijvoorbeeld Thaler \& Sunstein, 2003; Mitchell \& Utkus, 2004). Door complexiteit en keuzeoverbelasting zijn pensioenfondsdeelnemers mogelijk niet in staat te kiezen, stellen zij de keuze uit of weigeren zij actief te kiezen. Meer keuzes zal de beslissing eerder verslechteren dan verbeteren. Bovendien kunnen 
mensen niet leren van hun foute pensioenkeuzes omdat de beleggings- of spaarbeslissing niet over kan worden gedaan of gecorrigeerd. Ook overmatig vertrouwen en cognitieve dissonantie zijn redenen waarom mensen niet leren van hun foute pensioenkeuzes. Meer keuzes kunnen zelfs tot een afname van de deelname leiden. Meer mensen vermijden keuzes door de grotere complexiteit en de daaraan gekoppelde geanticipeerde spijt van een verkeerde keuze (Van Els e.a., 2006; Van Raaij \& De Groot, 2007; Kooreman \& Prast, 2010; Nijboer \& Boon, 2012; Bodie \& Prast, 2012).

\subsection{Suboptimale keuzes door defaults}

Naast gedragseffecten kunnen ook onvoldoende financiële kennis en expertise tot suboptimale pensioenkeuzes leiden. Van Rooij en Teppa (2008) concluderen dat financiële ongeletterdheid, beperkte mogelijkheid om financiële beslissingen te begrijpen en uitstelgedrag de belangrijkste verklaringen zijn om bij de default te blijven. Keuzevrijheid en verantwoordelijkheid ten aanzien van pensioensparen zijn gebaat bij een zekere financiële geletterdheid. Financiële kennis en vaardigheden zijn beperkt. De kennis over de eigen pensioenvoorziening neemt toe met de leeftijd, de opleiding en het inkomen; ook aandeelhouderschap heeft een positieve invloed. Mannen zijn beter op de hoogte dan vrouwen (Van Els e.a., 2006; Van Rooij, Kool \& Prast, 2007). Kortleve en Slager (2010, 16) stellen zelfs: consumenten snappen niets van pensioenen. In de neoklassieke economische theorie is pensioeneducatie belangrijk om de consument in staat te stellen betere financiële keuzes te kunnen maken. De gedragseconomische literatuur laat echter zien dat financiële educatie en pensioenkennis lang niet voldoende zijn om een passende pensioenopbouw te bevorderen. Het probleem is niet altijd het gebrek aan informatie, maar een informatieprocessingprobleem. Het probleem is te complex om een rationele keuze te maken, zelfs wanneer deelnemers de gewenste informatie hebben, ook al omdat bij pensioenkeuzes de tijdshorizon (zeer) lang is (Barr \& Diamond, 2008; Barr, 2012). Educatie kan zelfs contraproductief werken en tot slechtere beslissingen leiden door het toegenomen vertrouwen. Informatie en educatie leiden wel tot andere intenties met betrekking tot pensioensparen, maar minder tot feitelijke aanpassing van het gedrag; zij zijn geen antwoord op het merendeel van de gedragsproblemen (Mitchell \& Utkus, 2004; Bodie \& Prast, 2012). Ondanks dat de Nederlandse overheid en de pensioensector, conform de neoklassieke economische theorie, veel energie en geld hebben gestoken in communicatie, transparantie, bewustmaking en financiële educatie, is er weinig verandering in het pensioenbewustzijn. Optimale pensioenopbouw is te ingewikkeld (Prast \& Van Soest, 2014).

Dat mensen niet altijd rationeel hun eigenbelang nastreven, impliceert dat zij tegen zichzelf beschermd dienen te worden door de overheid die regels stelt en de markt corrigeert. Paternalisme met betrekking tot indexatie, premie- en beleggingsbeleid voorkomt ongewenste effecten van pensioenanalfabetisme onder deelnemers. Verplicht pensioensparen kan de vorm hebben van hard paternalisme, een pensioenplicht, of zacht paternalisme, automatisch lidmaatschap. Actief afmelden heeft de voorkeur boven actief aanmelden (Thaler \& Sunstein, 
2003; Barr \& Diamond, 2008; Kooreman \& Prast, 2010; Barr, 2012). Nijboer en Boon (2012) en Bodie en Prast (2012) bevelen vanuit de gedragseconomie aan de verplichtstelling van de aanvullende pensioenen te handhaven voor werknemers en deze aan te vullen met automatisch lidmaatschap voor zelfstandigen. Dat dwingt zelfstandigen een actieve keuze te maken.

Naast de verplichtstelling suggereert de gedragseconomie de introductie van een beperkt aantal relevante en betekenisvolle keuzes voor de individuele deelnemers met betrekking tot pensioenleeftijd, premiehoogte, aspiratie-inkomen en risicotolerantie. Het pensioenfonds kan bijvoorbeeld een default vaststellen met de mogelijkheid enkele procentpunten meer of minder te sparen. Met betrekking tot de beleggingen kunnen deelnemers naast een defaultrisicoprofiel actief kiezen voor een hoog risico met een hoge pensioenambitie of een laag risico met een lage pensioenambitie (Nijboer \& Boon, 2012; Bodie, Snippe \& Prast, 2008; Bodie \& Prast, 2012).

Door de sterk sturende werking is het zeer belangrijk de standaardoptie - de optie die de deelnemer automatisch kiest wanneer hij geen actieve keuze maakt - zorgvuldig te ontwerpen. De ideale default is volledig afgestemd op de persoonlijke omstandigheden en de individuele preferenties. In deze neoklassieke optimale situatie wordt de individuele welvaart gemaximeerd zonder dat de keuzevrijheid wordt belemmerd. Duidelijke, eenvoudige standaardwaarden kunnen worden toegepast als de pensioenfondsdeelnemers een homogene groep vormen. Wat goed is voor de een, is dan ook goed voor de ander (Bodie e.a., 2008; Bodie \& Prast, 2012; Nijboer \& Boon, 2012). De standaardopties zullen ingewikkelder en groter in aantal moeten zijn naarmate de deelnemerspopulatie heterogener is en meer uiteenlopende wensen heeft (Nijboer \& Boon, 2012; Bodie e.a., 2008). Los van privacykwesties, de optimale default kan onmogelijk worden bereikt als gevolg van prohibitieve kosten van het verzamelen van informatie over individuele mensen. Een praktische oplossing is het premie- en beleggingsbeleid te differentiëren naar homogene groepen deelnemers, waaronder naar leeftijd en bestaande pensioenopbouw. Elke groep wordt dan een passende standaardoptie aangeboden (Nijman \& Oerlemans, 2008; Bodie e.a., 2008; Bodie \& Prast, 2012; Prast \& Van Soest, 2014). Dit kan ertoe leiden dat de vastgestelde default aanzet tot een bepaalde keuze die niet optimaal blijkt te zijn voor de individuele pensioenfondsdeelnemers. Dit zal in het bijzonder het geval zijn indien de heterogeniteit van de deelnemers groot is. Van welvaartswinst door maatwerk en keuzevrijheid is dan mogelijk geen sprake meer. Bovendien is het niet denkbeeldig dat claims zullen worden ingediend en juridische procedures zullen worden opgestart door deelnemers indien de resultaten van de gestuurde keuzes tegenvallen.

\section{$5 \quad$ Witte vlek groeit door keuzemogelijkheden}

\subsection{Verplichtstelling versus concurrentie}

De verplichtstelling raakt aan de kern van het Nederlandse pensioenstelsel, namelijk de intergenerationele risicodeling en de solidariteit. Zonder verplicht- 
stelling is risicosolidariteit niet te organiseren. De verplichtstelling kan het draagvlak voor en de efficiëntie van intergenerationele risicodeling vergroten (Boender e.a., 2006). De Wet verplichte deelneming in een bedrijfstakpensioenfonds 2000 (Wet Bpf 2000) - de zogenaamde grote verplichtstelling - verplicht de werkgever een werknemer toe te laten tot de pensioenregeling van het bedrijf indien de werknemer tot een groep behoort voor wie een pensioenregeling geldt. Op verzoek van de representatieve sociale partners in een bedrijfstak kan de minister van Sociale Zaken en Werkgelegenheid de deelname aan een pensioenregeling voor alle of voor groepen van werknemers in die gehele bedrijfstak verplicht stellen. Ook zelfstandigen, waaronder de zzp'ers, kunnen onder de verplichtstelling worden gebracht. Afwijkend van de Wet Bpf 2000 is in de Wet verplichte beroepspensioenregeling (Wvb) een pensioenregeling verplicht gesteld, niet de deelneming in het fonds. Sinds 2007 stelt de verplicht op te richten beroepsvereniging de inhoud, waaronder de keuzemogelijkheden, van de pensioenregeling vast en kiest de uitvoerder. De leden hebben directe invloed op hun pensioenregeling. Dit maakt betere aanpassing mogelijk aan de grote verscheidenheid in behoeften en omstandigheden binnen de vrije beroepen. Verplichte deelneming geldt naast zelfstandige beroepsgenoten eveneens voor beroepsgenoten in loondienst. De uitvoerder bepaalt het indexatie-, premie- en beleggingsbeleid. Uitvoerders van verplicht gestelde bedrijfstakpensioenfondsen en beroepspensioenregelingen moeten een doorsneepremie in rekening brengen (Omtzigt, 2006; Van Els e.a., 2006; Van der Zwan, 2013; Van der Poel \& Lutjens, 2013). De verplichtstelling betekent solidariteit tussen werkgevers: bedrijven met een relatief jong personeelsbestand zijn solidair met bedrijven met een relatief oud personeelsbestand. De verplichte pensioendeelname voorkomt niet alleen concurrentie tussen werkgevers en werknemers binnen een bedrijfstak of beroepsgroep, maar ook oneerlijke concurrentie door buitenlandse bedrijven die geen premie betalen. Voor werkgevers is in een aantal gevallen dispensatie mogelijk van de verplichtstelling op basis van de Wet Bpf 2000 en de Wvb. De verplichtstelling draagt bij aan de stabiliteit van de Nederlandse arbeidsverhoudingen en aan de arbeidsrust. Dat is een belangrijk extern effect dat bijdraagt aan de Nederlandse concurrentiepositie. Naast het economisch doel, voorkomen van loonkostenconcurrentie binnen de bedrijfstak of beroepsgroep, heeft de verplichtstelling eveneens een sociaal doel: voorkomen van witte vlekken, dat wil zeggen werknemers zonder aanvullende pensioenregeling. Een nadeel van deze quasi-verplichtstelling ten opzichte van een algemene pensioenplicht is dat witte vlekken blijven bestaan (Delsen, 2001).

Door de verplichtstelling zijn pensioenfondsen monopolisten met aanzienlijke marktmacht. Meer marktwerking leidt in de neoklassieke economische theorie tot meer concurrentie tussen de verschillende pensioenaanbieders en dat komt zowel de prijs als de kwaliteit van het pensioenproduct ten goede in de vorm van een grotere efficiëntie, meer productinnovaties, betere beleggingsresultaten en meer keuzemogelijkheden en maatwerk (Bonenkamp e.a., 2011). Meer concurrentie tussen de uitvoerders kan een extra prikkel tot kostenverlaging en een opwaartse druk op performance betekenen (Verbond van Verzekeraars, 2014). Opheffen van de verplichtstelling doet echter afbreuk aan het relatieve succes van 
het Nederlandse pensioenstelsel: grote aantallen en relatief goedkoop verzekerde werknemers en een relatief hoge pensioenuitkering als gevolg van dit aanvullend pensioen. Ook het non-profitkarakter van pensioenfondsen draagt bij aan dit relatieve succes. De deelnemers zijn ook eigenaar, waardoor er minder belangentegenstellingen zijn tussen pensioenfondsbestuur en deelnemers. Het is de vraag of meer concurrentie in de Nederlandse pensioenpraktijk tot additionele kostenreductie en kwaliteitsverbetering zal leiden. Niet alleen zal meer marktwerking gepaard gaan met verlies aan schaalvoordelen en hogere marketingkosten (Van Ewijk e.a., 2014), ook zal winststreven ten koste van de beleggingsresultaten gaan en tot hogere premies en/of lagere uitkeringen leiden. Bovendien zal er onder concurrentiedruk (enige) uniformering in de pensioenregelingen plaatsvinden om de uitvoeringskosten te beperken.

De neo-institutionele theorie gaat ervan uit dat economische actoren niet over alle voor een beslissing relevante informatie beschikken en dat die informatie bovendien ongelijk is verdeeld. Tussen de pensioenuitvoerder en de deelnemer is sprake van (aanzienlijke) informatie-asymmetrie. Concurrentie kan ertoe leiden dat pensioenuitvoerders adverteren om te overtuigen in plaats van te adverteren om te informeren. Het bestaan van deze informatie-asymmetrie betekent ook dat afschaffing van de verplichtstelling leidt tot averechtse selectie (adverse selection): mensen met slechte risico's - vrouwen en hogere inkomens met een hoge levensverwachting - zullen zich het meest verzekeren. De (te) hoge pensioenpremies gaan ten koste van de toegankelijkheid. De witte vlek - het aantal werkenden dat geen aanvullend pensioen opbouwt - groeit. De markt faalt. Bepaalde groepen werkenden hebben de facto of de jure niet de mogelijkheid te kiezen. Vrijwillige pensioenplannen hebben aanzienlijke negatieve verdelingseffecten: indien fiscaal gefaciliteerd voordelig voor de welgestelden (Barr \& Diamond, 2008). Verplichtstelling maakt het mogelijk voor grote groepen werkenden, ondanks de grote verschillen, om een aanvullend pensioen op te bouwen. De verplichtstelling stelt de slechte risico's in staat om pensioen op te bouwen. De verplichtstelling betekent ook dat de goede risico's zich niet kunnen onttrekken. Dit verklaart waarom er bij de aanvullende pensioenen een forse herverdeling van mannen naar vrouwen en van laag- naar hoogopgeleiden plaatsvindt (Bonenkamp \& Ter Rele, 2013). Keuzevrijheid binnen pensioenregelingen leidt tot ongelijkheid. Keuzevrijheid leidt tot te weinig pensioensparen, vooral voor lage inkomens en voor vrouwen meer dan voor mannen. Lage inkomens en vrouwen plannen hun pensioen minder actief (Van Dalen, Henkens \& Hershey, 2006). Hogere inkomens en hoger opgeleide respondenten zijn meer geneigd een keuze te maken. Lagere inkomens ondernemen minder actie (Van Rooij e.a., 2007; Prast, Teppa \& Smits, 2012). ${ }^{4}$ Bovendien, fouten op financieel gebied raken de lagere inkomensgroepen meer dan de hogere inkomensgroepen. De verplichtstelling voorkomt ook dat mensen te weinig sparen voor hun pensioen. De pensioenbesparingen van werknemers met een laag inkomen, jonge werknemers, flexwerkers, werknemers in het midden- en kleinbedrijf en zelfstandigen nemen toe door de verplichtstelling. Afschaffing van de verplichtstelling kan eveneens tot moreel risico (moral hazard) leiden: liftersgedrag. Niet sparen kan rationeel zijn wanneer mensen verwachten in geval van 
problemen geholpen te worden door de overheid. Verplichte deelname voorkomt dit negatieve externe effect van keuzevrijheid. Verdelings- en externe effecten doen zich ook voor indien de deelnemer kan kiezen tussen het gespaarde pensioenkapitaal als uitkering ineens of als periodieke levenslange uitkering (annuïteit) (Nijboer \& Boon, 2012). Calculerende mensen met een hoge levensverwachting zullen voor de annuïteit kiezen. Mensen met een kortere levensverwachting zullen het pensioenbedrag ineens opeisen. Door kortzichtigheid bestaat het gevaar van te veel spaargeld opnemen op de pensioenleeftijd dat wordt aangewend voor consumptie. Hierdoor kunnen externe effecten optreden. De verplicht gestelde annuïteit voorkomt deze effecten.

\subsection{Toenemende arbeidsmobiliteit versus solidariteit}

Er wordt in Nederland steeds vaker van baan gewisseld, zeker aan het begin van de loopbaan. De samenstelling van de werkzame beroepsbevolking is de afgelopen tien jaar veranderd. Er zijn nu minder werknemers met een vaste arbeidsrelatie, en meer werknemers met een flexibel contract en zelfstandigen. Het aandeel vaste werknemers daalde van 75 procent in 2002 naar 69 procent in 2012 (CBS, 2012b). De vaste baan is dus nog steeds de norm. Ondanks de toenemende arbeidsmobiliteit en het groeiend aantal flexwerkers verandert de gemiddelde baanduur nauwelijks. Deze bedraagt in Nederland al jaren negen à tien jaar. Dit duidt op een toenemende tweedeling van het personeel binnen bedrijven en op de arbeidsmarkt. De veranderende samenstelling van de werkzame beroepsbevolking betekent ook een grotere witte vlek bij de aanvullende pensioenen. Momenteel heeft rond 20 procent van alle werkenden geen pensioen in de tweede pijler: rond 10 procent van de werknemers en meer dan de helft (57 procent) van de zelfstandigen (ING, 2014). Zij worden geacht zelf aanvullend pensioen te regelen. Het is de vraag of zij daartoe in staat zijn of dat voor hen ook een vorm van verplichting moet worden ingevoerd. Enquêteresultaten geven aan dat driekwart van de werknemers en 20 procent van de zelfstandigen denkt voldoende te sparen voor de oude dag (Van Rooij e.a., 2007). De toegenomen heterogeniteit en mobiliteit vormen niet alleen een argument voor meer keuzevrijheid en maatwerk binnen aanvullende pensioenen, maar kunnen ook een motief zijn om de verplichtstelling uit te breiden. Immers, toenemende arbeidsmobiliteit betekent dat ondernemingen minder belang hebben bij het aanbieden van solidariteit. Voor werknemers biedt het de mogelijkheid zich te onttrekken aan het collectief door over te stappen naar een werkgever zonder pensioenregeling, of zich als zelfstandige te vestigen. Hierdoor is de solidariteit - de risicodeling zowel tussen als binnen generaties - in het geding (De Laat e.a., 2000; Van Ewijk e.a., 2014; Dellaert \& Ponds, 2014). Met name verzekeraars stellen dat de keuzevrijheid van werkgevers voor een pensioenuitvoerder te sterk is ingeperkt en dat door belasting- en kostenvoordelen pensioenfondsen oneerlijk concurreren met verzekeraars. Werkgevers moeten de vrijheid krijgen om zelf te bepalen bij welke pensioenuitvoerder zij een regeling willen onderbrengen (Omtzigt, 2006; Verbond van Verzekeraars, 2014). Reeds in de jaren negentig werd gepleit voor afschaffing van de grote verplichtstelling. Om sociaaleconomische redenen - oneerlijke concurrentie, arbeidsrust en witte vlekken - werd de grote verplichtstelling gehandhaafd (Delsen, 
2001). Afschaffing van de grote verplichtstelling betekent het einde van de solidariteit tussen bedrijven met veel en weinig vrouwen en met veel jongeren en met veel ouderen. En leidt tot risicoselectie. Bedrijven zullen geneigd zijn voor die pensioenuitvoerder te kiezen met een jong deelnemersbestand. Pensioenuitvoerders met relatief veel oude deelnemers zijn immers duur vanwege de extra lasten door het omslagelement in de aanvullende pensioenen. Het voortbestaan van de duurder wordende pensioenfondsen wordt bedreigd. Voorstanders van meer marktwerking via afschaffing van de verplichte winkelnering (paternalisme) pleiten dan ook voor de overstap naar een beschikbare-premiestelsel, dat geen last heeft van deze risicoselectie. ${ }^{5}$

De kleine verplichtstelling betreft de afspraak dat werknemers die onder een cao vallen verplicht deelnemen aan de pensioenregeling van hun werkgever die bij deze cao hoort. Wanneer werknemers zelf kunnen kiezen voor een pensioenfonds, treedt volgens de institutionele economie zelfselectie op, die averechts werkt. Rationele deelnemers kiezen dat fonds dat het meeste voordeel biedt, dat wil zeggen dat qua risicoprofiel het beste aansluit. Jongere werknemers kiezen voor een fonds met relatief jonge deelnemers. Het voortbestaan van de sterk vergrijsde en duurder wordende pensioenuitvoerders wordt bedreigd. Rendementen komen in gevaar doordat minder risicovol belegd moet worden. Dit creëert onzekerheid en komt het vertrouwen niet ten goede. De gedragseconomie voorspelt dat slechts weinig deelnemers een andere pensioenaanbieder zullen kiezen. De grote meerderheid blijft bij dezelfde aanbieder, ook als dat tot een lager financieel resultaat leidt. Bovendien neemt de ongelijkheid toe. De ervaring met de Zorgverzekeringswet (Zvw) bevestigt dit. ${ }^{6}$

Er bestaat grote steun onder werknemers voor verplicht sparen voor pensioen. Van Els en anderen (2006) concluderen op basis van de DNB Household Survey dat de meerderheid van de Nederlandse werknemers goed kan leven met verplicht pensioensparen, hecht aan zekerheid van een toegezegde-uitkeringsysteem (DBsysteem) en geen behoefte heeft aan meer autonomie op pensioengebied. Van Rooij en collega's (2007) concluderen dat ruim driekwart (77 procent) van de respondenten (werkenden, werkzoekenden en studenten van 18 jaar en ouder) het verplichte karakter van pensioensparen als een voordeel ziet, 12 procent als nadeel en 11 procent heeft geen voorkeur. Van de voorstanders van het verplichte karakter is 44 procent blij geen tijd of energie te hoeven steken in het nadenken over de eigen pensioenbijdrage; 27 procent van de voorstanders geeft aan bang te zijn voor eigen uitstelgedrag en gebrek aan discipline en te weinig voor de oude dag opzij te zullen leggen. Ook uit recenter onderzoek (DNB, 2010) blijkt grote steun voor verplicht sparen voor het pensioen: 73 procent van de werknemers staat hier positief tegenover, 9 procent maakt het niet uit en 11 procent is tegen deze verplichting. De voorstanders vrezen te weinig te sparen als het geen verplichting is en geven aan dat zij het prettig vinden om niet te hoeven nadenken over de vraag hoeveel zij moeten sparen. Koenen (2014): De meeste deelnemers vinden het terecht dat deelname aan een pensioenregeling verplicht is, omdat veel mensen niet in staat worden geacht eigen verantwoordelijkheid te nemen 
voor hun financiële situatie in de toekomst. Onder zelfstandigen is er relatief weinig steun voor verplicht pensioensparen; rond 60 procent geeft aan hier geen voorstander van te zijn (ING, 2014).

De sociale partners hebben in de jaren negentig actie ondernomen om de witte vlekken bij de aanvullende pensioenen te verminderen. Nu het aantal witte vlekken weer groeit, is een logische volgende stap een algemene pensioenplicht. Risicodeling is de belangrijkste reden voor het bestaan van pensioenfondsen. Volgens Bonenkamp en anderen (2011) kan deze het best georganiseerd worden via een nationaal pensioenfonds door uitbreiding van de kleine verplichtstelling tot alle werkenden, werknemers en zelfstandigen. De kleine verplichtstelling wordt beperkt tot een pensioenopbouw van 80 procent van de fiscale ruimte. Maximaal 20 procent van de fiscale ruimte mag worden gespaard in de derde pensioenpijler. De default van 100 procent van de fiscale ruimte garandeert voldoende opbouw met risicodeling. Er blijft ook keuzevrijheid ten aanzien van de pensioenleeftijd met verrekening van pensioenen op een actuarieel neutrale basis. Het pensioenfonds bepaalt de regels. Bij invoering van een nationaal pensioenfonds speelt de grote verplichtstelling geen rol meer. Werkgevers dragen niet meer bij, noch dragen zij risico's. Na aanbesteding wordt de regeling uitgevoerd door een beperkt aantal grote organisaties die met elkaar concurreren om het aandeel in de pensioenregeling.

\section{Conclusies}

De introductie van maatwerk en keuzemogelijkheden betekent niet voor elk wat wils. Het neoklassieke optimale pensioencontract is onbereikbaar. In de praktijk hebben noch individuele, noch collectieve pensioenregelingen een optimale premie- en beleggingsmix. Paternalisme, beperking van de keuzevrijheid over premie en beleggingen binnen de pensioenfondsen, beschermen het individu tegen onverstandige beslissingen en werken welvaartsverhogend. De huidige verplichtstelling maakt het mogelijk grote aantallen werknemers relatief goedkoop te verzekeren van een relatief hoog pensioen. De mate waarin keuzevrijheid binnen en tussen pensioenregelingen wordt geprefereerd en wenselijk wordt geacht, hangt samen met het veronderstelde positieve effect van concurrentie op de prijs en de kwaliteit van de pensioenproducten, de (toenemende) heterogeniteit in omstandigheden en preferenties van de deelnemers, en de mate waarin individuele deelnemers geacht worden rationele keuzes te kunnen maken. In tegenstelling tot de neoklassieke economische theorie bevelen de realistischere gedragseconomie en de neo-institutionele theorie aan de verplichtstelling te handhaven of zelfs uit te breiden tot alle werkenden, werknemers en zelfstandigen.

Mensen waarderen keuzemogelijkheden en autonomie, ook al wordt hiervan de facto geen gebruik gemaakt. Om die reden zijn keuzemogelijkheden binnen de tweede pensioenzuil aan te bevelen. Keuzevrijheid kan betrekking hebben op de opbouwfase en de uitkeringsfase van pensioen. Slechts een kleine minderheid maakt gebruik van de bestaande relatief eenvoudige keuzemogelijkheden, zoals 
pensioenleeftijd, deeltijdpensioen en hoog-laagpensioen. Deels hangt dit samen met onwetendheid, deels met desinteresse. De welvaartswinst van meer keuzes in de opbouwfase is twijfelachtig. Voor de grote meerderheid van de Nederlanders zijn meer keuzemogelijkheden en vrijheid op pensioengebied eerder een extra probleem dan een oplossing. De keuzes op pensioengebied komen bovendien bovenop de al bestaande keuzes in andere gebieden. De complexiteit van de pensioenkeuze kan worden gereduceerd door het aantal opties beperkt te houden. De vraag is echter of hiermee ook het dominante passief kiezen kan worden voorkomen. Immers, de defaultoptie is cruciaal bij pensioenkeuzes. Dit maakt bovendien niet alleen sturing, maar ook manipulatie van de keuzes mogelijk. Verwacht mag worden dat slechts een zeer kleinere minderheid daadwerkelijk gebruik zal maken van additionele keuzemogelijkheden in de opbouwfase. Gezien de complexiteit is het bovendien goed voorstelbaar dat deze pensioenfondsdeelnemers dezelfde actieve pensioenkeuzes maken. Heterogeniteit is een noodzakelijke maar geen voldoende voorwaarde voor de introductie van keuzemogelijkheden. Naast verdelingsproblemen gaat het bieden van keuzemogelijkheden eveneens gepaard met privacyproblemen en aanzienlijke transactiekosten voor alle betrokken partijen, pensioenuitvoerders, werkgevers en deelnemers, die evenals externe effecten in economische analyses vaak buiten beschouwing blijven.

\section{Noten}

1 De uitgestelde loongedachte ligt ook ten grondslag aan de fiscale facilitering van pensioensparen via de zogenoemde omkeerregel.

2 In paragraaf 4 staan de gedragseconomie en keuzevrijheid centraal en in paragraaf 5 wordt nader ingegaan op de neo-institutionele economie in relatie tot keuzevrijheid op pensioengebied.

3 In paragraaf 4 wordt nader ingegaan op het gebruik van deze defaults.

4 Concurrentie impliceert mogelijk ook de introductie van risicoselectie door de pensioenaanbieder. De ervaring met zorgpolissen leert dat, hoewel risicoselectie in de Zorgverzekeringswet $(\mathrm{Zvw})$ verboden is, jongeren en hoogopgeleiden via trucs voor dezelfde polis gunstigere voorwaarden krijgen dan ouderen en laagopgeleiden. De solidariteit wordt hierdoor ondermijnd.

5 Bij de beschikbare premieregeling of premieovereenkomst wordt voor elk verzekerd jaar een bedrag aan pensioenpremie beschikbaar gesteld door de werkgever, waarvoor een pensioen wordt ingekocht. Het bedrag kan afhankelijk zijn van het salaris of de winst. Dit is een strikt individueel systeem, waarbij het uiteindelijke pensioen volledig afhankelijk is van de betaalde premie en de beleggingsopbrengsten.

6 Tussen 2009 en 2014 heeft de mobiliteit onder verzekerden gefluctueerd tussen de 3,3 procent en 7,2 procent. Sinds de invoering van de Zvw in 2006 is driekwart van de verzekerden nog niet overgestapt. Verzekerden die weinig overstappen, hebben relatief hoge zorgkosten, zijn relatief oud en wonen vaak in de meer dunbevolkte gebieden van het land. Jongeren en gezonde verzekerden stappen vaker over (KPMG, 2014). 


\section{Literatuur}

Barr, N. (2012). Credit crisis and pensions: international scope. In: A.L. Bovenberg, C. van Ewijk \& E. Westerhout (Eds.), The Future of Multi-Pillar Pensions. Cambridge: Cambridge University Press, 90-141.

Barr, N., \& Diamond, P. (2008). Reforming pensions. Principles and policy choices. Oxford: Oxford University Press.

Benders, J., \& Delsen, L. (2007). Ervaringen met arbeidsvoorwaarden à la carte in Nederland. Tijdschrift voor HRM, 10 (1): 53-70.

Bikker, J.A., \& Dreu, J. de (2006). Uitvoeringskosten van pensioenverstrekkers. In: S.G. van der Lecq \& O.W. Steenbeek (red.), Kosten en baten van collectieve pensioensystemen. Deventer: Kluwer, 69-96.

Bodie, Z., \& Prast, H.M. (2012). Rational pensions for irrational people, behavioral science lessons for the Netherlands. In: A.L. Bovenberg, C. van Ewijk \& E. Westerhout (Eds.), The Future of Multi-Pillar Pensions. Cambridge: Cambridge University Press, 299-329.

Bodie, Z., Snippe, J., \& Prast, H.M. (2008). Individuele pensioenoplossingen: doel, vormgeving en illustratie (NEA Paper 10). Tilburg: Netspar Economische Adviezen.

Boender, C.G.E., Bovenberg, A.L., Hoogdalem, S. van, \& Nijman, Th.E. (2006). Optimale risicodeling in individuele en collectieve pensioencontracten. In: S.G. van der Lecq \& O.W. Steenbeek (red.), Kosten en baten van collectieve pensioensystemen. Deventer: Kluwer, 97-118.

Bonenkamp, J., Meijdam, L., Ponds, E., \& Westerhout, E. (2011). Het pensioenfonds van de toekomst: risicodeling en keuzevrijheid (NEA Paper 44). Tilburg: Netspar Economische Adviezen.

Bonenkamp, J., \& Rele, H. ter (2013). Herverdeling door pensioenregelingen: een integrale analyse van de AOW en de aanvullende pensioenen. TPEdigitaal, 7 (1): 51-65

Borgers, A.C.T., \& Pownall, R.A.J. (2014). Attitudes towards socially and environmentally responsible investment. Journal of Behavioral and Experimental Finance, 1: 27-44.

Bovenberg, L., Ewijk, C. van, \& Westerhout, E. (Eds.) (2012). The Future of Multi-Pillar Pensions. Cambridge: Cambridge University Press.

CBS (2012a). Helft werknemers heeft weinig vertrouwen in eigen pensioenfonds. Webmagazine, 28 mei. Den Haag: Centraal Bureau voor de Statistiek.

CBS (2012b). Minder werknemers met vaste baan. Webmagazine, 10 december. Den Haag: Centraal Bureau voor de Statistiek.

Commissie Frijns (2010). Pensioen: 'onzekere zekerheid'. Eindhoven: Commissie Beleggingsbeleid en Risicobeheer.

Commissie Goudswaard (2010). Een sterke tweede pijler: naar een toekomstbestendig stelsel van aanvullende pensioenen. Den Haag: Commissie Toekomstbestendigheid Aanvullende Pensioenregelingen.

Dalen, H. van, \& Henkens, K. (2014). Goedkope praatjes over keuzevrijheid in pensioen. Me Judice, 6 november.

Dalen, H.P. van, Henkens, K., \& Hershey, D. (2006). Keuzevrijheid en pensioen: vloek voor de een, zegen voor de ander. Demos, 21 (1): 1-4.

Dellaert, B., \& Ponds, E. (2014). Pensioen op maat: heterogeniteit en individuele keuzevrijheid in pensioenen. In: L. Bovenberg, C. van Ewijk \& T. Nijman (red.), Toekomst voor aanvullende pensioenen (Preadviezen van de Koninklijke Vereniging voor de Staathuishoudkunde 2014), Amsterdam, 45-71.

Delsen, L. (2001). Exit Poldermodel? Sociaal-economische ontwikkelingen in Nederland. Assen: Van Gorcum. 
Delsen, L. (2012). Duurzaam beleggen door pensioenfondsen. In: L. Delsen \& T. van den Hoogen (red.), Maatschappelijk Verantwoord Ondernemen in de Polder. MVO in Nederland bezien vanuit de economie en theologie. Assen: Van Gorcum, 91-121.

Delsen, L., Benders, J., \& Smits, J. (2006). Choices Within Collective Labour Agreements à la Carte in the Netherlands. British Journal of Industrial Relations, 44 (1): 51-72.

Delsen, L., \& Kantarci, T. (2014). Analysis of the Stated Preferences for Risk and Uncertainty in Pension Plans in the Netherlands (Paper voor de Netspar Pension Day, 28 november). Utrecht.

Delsen, L., \& Smits, J. (2014). The Rise and Fall of the Dutch Savings Schemes (Netspar Discussion Paper nr. 02/2014-008). Tilburg: Netspar.

Dietvorst, G.J.B., \& Visser, M.R. (2012). Keuzemogelijkheden en pensioen: een onderzoek naar keuzemogelijkheden rond de uitkeringsfase van pensioen. Tilburg: CompetenceCentre for Pension Research.

DNB (2010). Naar nieuwe pensioencontracten: wat zijn de voorkeuren van deelnemers? DNB Household Survey. Amsterdam: De Nederlandsche Bank. Te raadplegen via www.dnb. $\mathrm{nl} /$ binaries/Bijlage\%20Pensioenvoorkeuren_tcm46-243710.pdf.

DNB (2012). Herstel van vertrouwen van huishoudens in de financiële sector blijft tot nu toe uit. DNBulletin, 20 juni. Amsterdam: De Nederlandsche Bank.

Els, P.J.A. van, Rooij, M.C.J. van, \& Schuit, M.E.J. (2006). Nut en noodzaak van verplicht pensioensparen. In: S.G. van der Lecq \& O.W. Steenbeek (red.), Kosten en baten van collectieve pensioensystemen. Deventer: Kluwer, 191-220.

Erbé, D. (2008). Stille kapitalisten. Een sociologisch onderzoek over de invloed en controle van deelnemers op het beleggingsbeleid van hun pensioenfonds (masterscriptie Sociologie). Amsterdam: Universiteit van Amsterdam.

Ewijk, C. van, Lever, M., Bonenkamp, J., \& Melhkopf, R. (2014). Pensioen in discussie. CPB Policy Brief, 2014-06. Den Haag: Centraal Planbureau/Netspar.

FNV (2014). Samen delen, een sterke keuze. Pensioen in beweging! Klaar voor de toekomst. Amsterdam: Stichting FNV Pers.

ING (2014). Meerderheid zelfstandigen bouwt geen pensioen op. ING Economisch Bureau/ZZP Barometer.

Iyengar, S.S., \& Lepper, M.R. (2000). When choice is demotivating: can one desire too much of a good thing? Journal of Personality and Social Psychology, 79 (6): 995-1006.

Kloosterman, R., \& Schmeets, H. (2014). Meningen over pensioenkwesties. Sociaal Economische trends 2014, 2. Den Haag: Centraal Bureau voor de Statistiek.

Koenen, B. (2014). Issuemonitor 2014 pensioenen. Amsterdam: Veldkamp.

Kooreman, P., \& Prast, H. (2010). What does behavioral economics mean for policy? Challenges to savings and health policies in the Netherlands. De Economist, 158 (2): 101-122.

Kortleve, N., \& Slager, A. (2010). Consumenten aan het roer. Strategische toekomstvisies voor de Nederlandse pensioensector (NEA Paper 27). Tilburg: Netspar Economische Adviezen.

KPMG (2014). Evaluatie Zorgverzekeringswet. Eindrapportage. KPMG Plexus.

Laat, E.A.A. de, Ven, M.E.A.J. van de, \& Canoy, M.F.M. (2000). Solidariteit, keuzevrijheid en transparantie. De toekomst van de Nederlandse markt voor oudedagsvoorzieningen.

Den Haag: Centraal Planbureau.

Lecq, S.G. van der, \& Steenbeek, O.W. (2006). Samenvatting en conclusies. In: S.G. van der Lecq \& O.W. Steenbeek (red.), Kosten en baten van collectieve pensioensystemen.

Deventer: Kluwer, 69-96.

Lewin, K. (1945). The Research Center for Group Dynamics at Massachusetts Institute of Technology. Sociometry, 8 (2): 126-135 
Lindenberg, S. (2001a). Social rationality versus rational egoism. In: J. Turner (Ed.), Handbook of Sociological Theory. New York: Kluwer/Plenum, 635-668.

Lindenberg, S. (2001b). Intrinsic motivation in a new light. Kyklos, 54 (2/3): 317-342.

Mitchell, O.S., \& Utkus, S.P. (Eds.) (2004). Pension Design and Structure: New Lessons from Behavioral Finance. Oxford: Oxford University Press.

Motivaction (2009). Pensioenvertrouwensbarometer 2009-2011. Meningen over sparen en beleggen van pensioenpremie. Amsterdam: Motivaction International.

Motivaction (2012). Samenvatting van het Motivaction-onderzoek deelnemers Pensioenfondsen. Te raadplegen via www.natuurenmilieu.nl/media/365224/factsheet_motivaction_ -_deelnemers_pensioenfondsen.pdf.

Nijboer, H., \& Boon, B. (2012). Pension contract design and free choice: Theory and practice (Netspar Panel Paper 27). Tilburg: Netspar.

Nijman, T., \& Oerlemans, A. (2008). Maatwerk in Nederlandse pensioenproducten (NEA Paper 8). Tilburg: Netspar Economische Adviezen.

Omtzigt, P.H. (2006). De grote verplichtstelling. In: S.G. van der Lecq \& O.W. Steenbeek (red.), Kosten en baten van collectieve pensioensystemen. Deventer: Kluwer, 221-237.

Poel, M. van der, \& Lutjens, E. (2013). De houdbaarheid van verplicht gestelde bedrijfstakpensioenfondsen en beroepspensioenregelingen. Toetsing aan het mededingingsrecht en het vrij verkeer van diensten en vestiging, VU Expertisecentrum Pensioenrecht. Amsterdam: Vrije Universiteit.

Prast, H.M., \& Soest, A.H.O. van (2014). Pensioenbewustzijn (Netspar Panel Papers 37). Tilburg: Netspar.

Prast, H., Teppa, F., \& Smits, A. (2012). Is information overrated? Evidence from the pension domain (DNB Working Paper No. 360). Amsterdam: De Nederlandsche Bank.

Raaij, F. van (2009). Hoe krijgt de financiële sector het vertrouwen weer terug?, Me Judice, 14 mei.

Raaij, F. van, \& Groot, M. de (2007). Nadelige gevolgen van te veel keuze. Dossier Toekomst van de consument. Economisch Statistische Berichten, 92 (4508S): 4-9.

Rooij, M.C.J. van, Kool, C.J.M., \& Prast, H.M. (2007). Risk-return preferences in the pension domain: are people able to choose? Journal of Public Economics, 91: 701-722.

Rooij, M. van, \& Teppa, F. (2008). Choice or no Choice: What Explains the Attractiveness of Default Options (Discussion Paper 11/2008-032). Tilburg: Netspar.

Schwartz, B. (2004). The Paradox of Choice. Why More is Less. New York: HarperCollins.

SER (2015). Ontwerpadvies Toekomst pensioenstelsel. Commissie Toekomst Pensioenstelsel. Simon, H.A. (1957). Models of Man. New York: Wiley.

Thaler, R.H., \& Sunstein, C.R. (2003). Libertarian Paternalism. The American Economic Review, 93 (2): 175-179.

Verbond van Verzekeraars (2014). Mee met de tijd. Naar een toekomstbestendig pensioenstelsel. Den Haag: Verbond van Verzekeraars.

Williamson, O.E. (1985). The Economic Institutions of Capitalism. New York: The Free Press.

Zwan, N.A.J. van der (2013). Collectieve zeggenschap in het Nederlandse pensioenstelsel: de beroepspensioenvereniging (AIAS Working Paper 128). Amsterdam: Universiteit van Amsterdam. 